\title{
Academic experience of Psychology students: Differences between beginners and graduating
}

\author{
Vivência acadêmica de alunos de Psicologia: \\ diferenças entre iniciantes \\ e concluintes
}

\author{
Monalisa de Cássia FOGAÇA ${ }^{1}$ \\ Daniel Carvalho de MATOS ${ }^{2}$ \\ Jonas BORSETTI ${ }^{3}$ \\ Vanessa Diana DI RIENZO \\ Leidiana Peixoto RIBEIRO' \\ Rosana Zimbardi MARTINS ${ }^{1}$ \\ Izabela Galindo SILVA ${ }^{1}$
}

\begin{abstract}
There is a high incidence of academic failure in university students which manifests in different ways, such as: low ratings, delayed subjects, course changes and dropouts. We conducted a cross-sectional study with 262 students, which we evaluated the academic experience of the student of Psychology. The Reduced-Academic Experiences Questionnaire was applied. For each year studied we perceived statistical differences, taking into account the period the student studies: $1^{\text {st }}$ year study and institution item $(p=0.039$ and 0.000$) ; 2^{\text {nd }}$ year interpersonal and institutional item ( $p=0.014$ and 0.005$)$. We found statistical differences between morning and night period in $4^{\text {th }}$-year-students in relation to personal and interpersonal items ( $p=0.056$ and 0.038 ). In relation to students from previous years compared to $5^{\text {th }}$-year-students, the significant statistical results were: $1^{\text {st }}$ and $5^{\text {th }}$ in personal $(p=0.004)$, study $(p=0.001)$ and institutional items $(p=0.001), 2^{\text {nd }}$ and $5^{\text {th }}$ in interpersonal $(p=0.050)$ and institutional items $(p=0.023), 3^{\text {rd }}$ and $5^{\text {th }}$ year in personal item $(p=0.000)$. We concluded the areas identified above present some domains which certainly best describe the academic adaptation, thus serving as goals for future investigations, in order to intervene and avoid problems in the adaptation of the entrant student at university.
\end{abstract}

Keywords: Higher education; Students; Psychology.

\section{Resumo}

Há grande incidência de insucesso acadêmico nos alunos universitários a qual se manifesta de diversos modos, como: baixas avaliações, disciplinas em atraso, mudanças de curso e abandonos. Foi realizado um estudo transversal com

$\checkmark v \nabla v$

1 Universidade Nove de Julho, Curso de Psicologia, Departamento de Saúde III. São Paulo, SP, Brasil.

2 Universidade CEUMA, Curso de Psicologia, Departamento de Ciências Humanas. R. dos Castanheiros, Jardim Renascença, 65075-120, São Luís, MA, Brasil. Correspondência para/Correspondence to: D.C. MATOS. E-mail: <monalisa.cassia@uol.com.br>.

${ }^{3}$ Universidade Nove de Julho, Curso Engenharia, Departamento de Exatas. São Paulo, SP, Brasil. 
262 alunos, onde avaliou-se a vivência acadêmica do estudante de Psicologia. O Questionário de Vivências Acadêmicas Reduzido foi aplicado. Em relação a cada ano estudado, perceberam-se diferenças estatísticas entre os itens, levando em conta o período que o aluno estuda: $1^{\circ}$ ano, itens estudo e instituição $\left(p=0,039\right.$ e 0,000); e $2^{\circ}$ ano, itens interpessoal e institucional ( $p=0,014$ e 0,005). Encontraram-se diferenças estatísticas entre o período matutino e noturno nos alunos do $4^{\circ}$ ano em relação aos itens pessoal e interpessoal ( $p=0,056$ e 0,038 ). No que diz respeito aos alunos de anos anteriores em comparação aos do $5^{\circ}$ ano, os resultados estatísticos significativos foram: $1^{\circ}$ e $5^{\circ}$ anos nos itens pessoal $(p=0,004)$, estudo $(p=0,001)$ e institucional $(p=0,001) ; 2^{\circ}$ e $5^{\circ}$ anos nos itens interpessoal $(p=0,050)$ e institucional $(p=0,023)$; e $3^{\circ}$ e $5^{\circ}$ anos no pessoal $(p=0,000)$. Concluiu-se que as áreas acima identificadas representam alguns domínios os quais, seguramente, melhor descrevem a adaptação acadêmica, servindo, dessa forma, como objetos para investigações futuras, a fim de intervir e prevenir problemas na adaptação do estudante ingressante na universidade.

Palavras-chave: Educação superior; Estudantes; Psicologia.

The academic life of college students is subjected to the influence of various stressful events. According to Monteiro, Freitas, and Ribeiro (2007), symptoms of both a physiological and psychological nature in this population are correlated with stressors. Among stressors, the following are highlighted: the beginning of a new cycle of friends; adaptation to new schedules; financial problems; and being away from the family environment. Physiological symptoms include tachycardia, hypertension, hyperactivity, while psychological symptoms are anxiety, anguish, insomnia, and excessive preoccupation.

Stressful events may originate from three types of environments: the external environment (e.g. cold and heat); the social environment (e.g. unhealthy occupation); and the internal environment (e.g. fear, anguish). Monteiro et al. (2007) conducted a study addressing situations that generate anxiety among the undergraduate nursing students of the Universidade Federal do Piauí and this qualitative exploratory study included semi-structured interviews with 22 students, of which 15 were women. The interviewees' responses were analyzed according to three categories: stressful situations, stress symptoms, and academic performance. In general, the authors verified that the students' symptoms were of a physiological and emotional nature and negatively affected their academic performance.

In regard to the theme stress and the development of coping strategies in the sphere of higher education, Bardagi and Hutz (2011) help to better understand academic trajectories and how to devise interventions to prevent problems identified by students. Bardagi and Hutz note that studies addressing students from the heath field predominate and that these report a great diversity of stressors. The authors contend that when individuals perceive a given situation as a stressor, they tend to experience unpleasant emotions and establish strategies to reduce distress. These strategies are mainly focused on emotion and seek to regulate emotional responses to stressful events by avoiding sources of stress.

Bardagi and Hutz (2011) reinforce gender differences, arguing that women experience a greater level of academic stress. Age is another variable assessed in studies showing that younger students are more vulnerable to psychological distress and to a less efficient use of coping strategies centered on emotion. Even though Bardagi and Hutz (2011) highlight that studies assessing stress and the development of coping strategies have mainly been conducted with students from the health fields, they note that the results of these studies cannot be generalized, since students from other fields should be also assessed. Additionally, Bardagi and Hutz also question the arguments of authors suggesting that undergraduate nursing students are more sensitive and vulnerable to the effects of stressful events, since little is known in regard to students from other fields.

An alarming problem, mainly observed in private Brazilian universities, involves the difficulty students from various fields present in reading comprehension. Various researchers have used the 
Cloze technique to measure reading comprehension (Oliveira \& Santos, 2005; Santos, Suehiro, \& Oliveira, 2004; Silva \& Witter, 2008). Silva and Witter conducted a study with students from the Psychology program of a private college. The specific objective was to assess reading comprehension and its correlation with specific courses. The Cloze test was applied at the beginning and at the end of the school period. The analysis of the results showed that the level of reading comprehension was not satisfactory and no significant improvement was observed at the end of the school year. The justification of the authors to perform the study was that identifying college students' level of reading comprehension is beneficial to the development of more efficient educational practices. Silva and Witter (2008) discussed the poor performance of psychology students in reading comprehension, noting that it results from deficiencies at the elementary and middle school levels, lack of or inappropriate use of reading strategies, lack of self-control, and lack of attention.

It is important to note that, for certain authors in the field of Psychology (e.g. De Rose, 2005; Skinner, 1957/1978), reading is a verbal behavior (i.e. they refer to language). This type of verbal behavior (reading) is also called a textual behavior, while a reader produces a sequence of verbal responses to a text. According to Skinner, the textual behavior is established because it involves verbal responses (reading) aloud, but presumably those responses remain in a sub-vocal level when reading is silent. De Rose emphasizes, however, that textual behavior is not the same as reading or, more specifically, not the same as reading with comprehension. In this sense, even if a person emits verbal responses (aloud or subvocal) under the control of a text, that does not mean that s/he fully understands it. From the perspectives of these authors, reading with comprehension refers to a more complex repertoire. In regard to the reality of many students from private colleges, one has to consider that many of these students arrive at the university with difficulties that have historical roots (problems starting at the elementary school level). Studies indicate difficulty in reading with comprehension, but the problem could also be related to so-called textual behavior.

Given the previous discussion, considering the problems that students face in the context of the university (e.g. problems with reading comprehension, difficulty with stressors existing in this environment, and difficulty in developing coping strategies), the topic of academic life has emerged in recent studies (Lopes \& Reinaldo, 2012; Mognon \& Santos, 2013; Sousa, Bardagi, \& Nunes, 2013). This emergence emphasizes the need to deepen the theme in order to devise preventive educational goals to deal with pedagogical and interpersonal problems that come to light in the students training process.

The study by Lopes and Reinaldo (2012) conducted with nursing students highlights the academic experiences, reported over the course of therapeutic workshops, developed based on students critical thinking, problem-solving capacity, integral approach to the psychiatric patient, and therapeutic listening, among other factors important for the training of nursing professionals.

Sousa et al. (2013) used the brief version of the Questionário de Vivências Acadêmicas (Academic Experiences Questionnaire) elaborate for Almeida, Soares, and Ferreira (2002) and assessed the academic experiences of students, both those admitted under affirmative action and those that were not. Those admitted under affirmative action scored lower that their counterparts on the interpersonal dimensions of the academic experiences instrument and higher on the Personal and Institutional dimensions, while no differences were found in regard to self-efficacy. The author understands this as meaning that the difficulty of students admitted under affirmative action in interpersonal relationships accrued from prejudice and lack of trust that the affirmative action system faces in Brazil.

Mognon and Santos (2013), investigated the association between academic experience and career development using Questionário de Vivências Acadêmicas-Reduzido (QVA-r, Questionnaire of Academic Experience) and Scale of Career Development. They verified that the constructs of 
academic life and career development were positively correlated so that experiences acquired in the university are associated with indicators of career development.

Therefore, this study's aim was to investigate the academic experience of Psychology students of a private school in São Paulo, Brazil, based on the view that one of the growing concerns of universities is the high rate of academic failure manifested in multiple ways, such as: students' low classification, absenteeism, delayed course completion, change of programs, and dropping out.

\section{Method}

\section{Participants}

This cross-sectional study was conducted with female and male students from the $1^{\text {st }}$ to the $5^{\text {th }}$ year $(\mathrm{N}=262)$, both from the morning and night periods, of a total of 1,825 students enrolled in the $2^{\text {nd }}$ semester 2010 of a private university in the state of São Paulo, Brazil, according to the following distribution: $1^{\text {st }}$ year (68), $2^{\text {nd }}$ year (45), $3^{\text {rd }}$ year (61), $4^{\text {th }}$ year $(35)$ and $5^{\text {th }}$ year $(53)$.

\section{Instruments}

We applied the Questionário de Vivências Acadêmicas-Reduzido (QVA-r, Questionnaire of Academic Experience) (Almeida et al., 2002). Its purpose is to identify the perceptions and experiences of students to better understand the process of academic integration. This version is composed of 55 items divided into the following dimensions: Career (12 items); Personal (15 items); Interpersonal (13 items); Studying (11 items); and Institutional (7 items).

\section{Procedures}

Data were collected in classrooms according to the availability of the participants, i.e., convenience sampling. All the participants signed Free and Informed Consent Forms and the study was approved by the Institutional Review Board (Process $\left.n^{\circ} 361159 / 10\right)$.

Data were analyzed using the Mann-Whitney test. First, because there was no hypothesis; the objective was only to verify the academic experience of the students and not to prove anything. The $t$ test could be used because variances were not homogeneous, though there is a correction factor for the variance in regard to its non-homogeneity. Similarly, as we worked with non-parametric data, it would not be feasible to use the Analysis of Variance (Anova), which compares averages and variance of samples. Finally, the Mann-Whitney test can be applied for qualitative variables while the $t$ test requires at least interval variables. Additionally, the instrument used served to assess academic experience and does not consider antecedent elements or their effects.

\section{Results}

The average age of students was 28.4 years old, while $79.77 \%$ of the respondents were women and $20.23 \%$ were men. No significant differences were found among the students in the period (Table 1).

Significant differences were found in regard to school year: differences in the $1^{\text {st }}$ year concerned the studying and institutional items ( $p=0.039$ and $0.000)$; for the $2^{\text {nd }}$ year, they concerned the interpersonal and institutional items $(p=0.014$ and $0.005)$. No significant differences were found between the morning and night periods among $3^{\text {rd }}$ year students, while significant differences were found between the morning and night periods among $4^{\text {th }}$ year students in regard to the personal and interpersonal items ( $p=0.056$ and 0.038 ). No differences were found among $5^{\text {th }}$ year students in either of the periods (Table 2 ). The results considering comparison between $5^{\text {th }}$ year students and those from previous years include: $1^{\text {st }}$ and $5^{\text {th }}$ year students presented differences in regard to the personal ( $p=0.004)$, studying $(p=0.001)$ and institutional 
Table 1

Comparison of the QVAr dimensions among Psychology students attending the morning and night classes. Universidade Nove de Julho, São Paulo, Brazil, 2010

\begin{tabular}{lcc}
\hline QVAr Dimensions & Average scores (Morning and Night) & $p$ \\
\hline Personal & $134.54 \times 127.26$ & 0.436 \\
Interpersonal & $126.10 \times 136.17$ & 0.281 \\
Career & $126.74 \times 135.50$ & 0.348 \\
Studying & $130.09 \times 131.96$ & 0.841 \\
Institutional & $131.53 \times 130.44$ & 0.907 \\
\hline
\end{tabular}

Note: QVAr: Questionário de Vivências Acadêmicas - Reduzido.

Table 2

Comparison among the QVAr dimensions and the morning and night classes considering the school year. Universidade Nove de Julho, São Paulo, Brazil, 2010

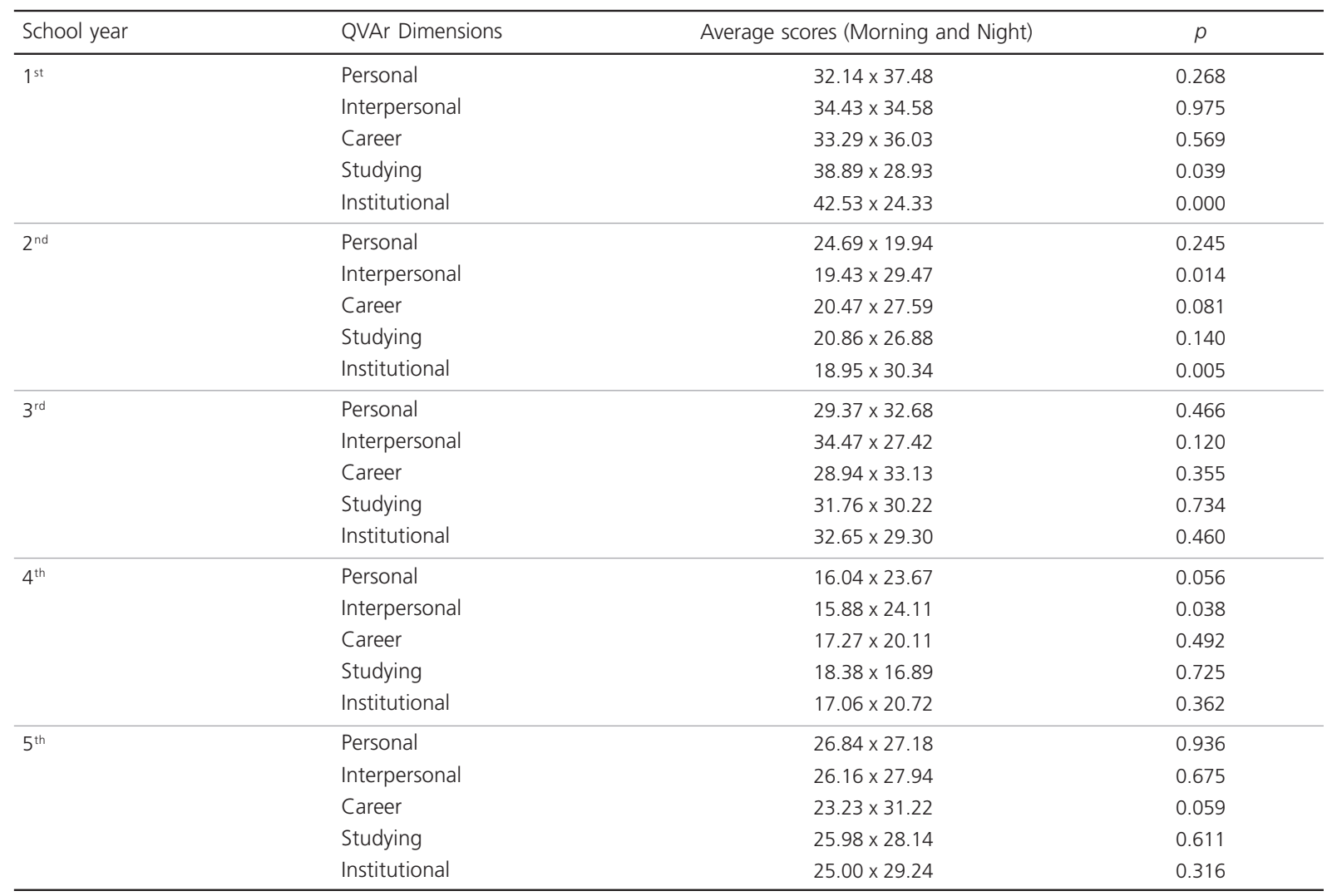

Note: QVAr: Questionário de Vivências Acadêmicas - Reduzido.

$(p=0.001)$ items; $2^{\text {nd }}$ and $5^{\text {th }}$ year students in the interpersonal ( $p=0.050)$ and institutional $(p=0.023)$ items; $3^{\text {rd }}$ and $5^{\text {th }}$ year students presented differences for the personal item $(p=0.000)$; and no significant differences were found between the $4^{\text {th }}$ year and $5^{\text {th }}$ year students in regard to the dimensions assessed by QVAr (Table 3).

\section{Discussion}

First, a comparison was performed between students attending the morning and night periods in accordance with year in school. Difficulties were verified among $1^{\text {st }}$ year students in regard to adapting to studying, which may be related to the 
Table 3

Comparison between beginning and graduating students in regard to the average scores obtained in the QVAr dimensions. Universidade Nove de Julho, São Paulo, Brazil, 2010

\begin{tabular}{cccccc}
\hline School year & Personal & Interpersonal & Career & Studying & Institutional \\
\hline $1 \times 5$ & $52.94 \times 71.34$ & $61.36 \times 60.54$ & $64.79 \times 56.14$ & $70.50 \times 48.81$ & $70.38 \times 48.97$ \\
& $p=0.004$ & $p=0.898$ & $p=0.178$ & $p=0.001$ & $p=0.001$ \\
$2 \times 5$ & $37.60 \times 43.63$ & $34.64 \times 45.25$ & $35.31 \times 44.89$ & $41.16 \times 41.69$ & $33.43 \times 45.92$ \\
& $p=0.273$ & $p=0.050$ & $p=0.081$ & $p=0.923$ & $p=0.023$ \\
$3 \times 5$ & $47.26 \times 69.28$ & $55.74 \times 59.53$ & $56.55 \times 58.59$ & $61.86 \times 52.48$ & $57.97 \times 56.96$ \\
& $p=0.000$ & $p=0.541$ & $p=0.741$ & $p=0.130$ & $p=0.871$ \\
$4 \times 5$ & $38.51 \times 48.45$ & $40.90 \times 46.88$ & $42.77 \times 45.64$ & $47.97 \times 42.21$ & $44.77 \times 44.32$ \\
& $p=0.074$ & $p=0.282$ & $p=0.605$ & $p=0.300$ & $p=0.935$ \\
\hline
\end{tabular}

Note: QVAr: Questionário de Vivências Acadêmicas - Reduzido.

fact that many students in the night period work during the day and those studying in the morning had recently left high school. In regard to this subject (that of comparing college students attending different schools years and day periods), Fogaça et al. (2012) support the idea that students attending the night period usually experience academic activities as if they were a second job. Many of these students work during the day and attend the university at night. In the case of this study, entering college represents a considerable change in the lives of students attending both periods (morning and night).

First and $2^{\text {nd }}$ year students presented difficulties adapting to the institution. These difficulties occur because it is a time period in which students are still unsure whether they made the right choice in regard to entering the program. Those attending the $2^{\text {nd }}$ year still experience challenges in regard to interpersonal relationships. These difficulties, among the institution's students who responded to the questionnaire, may be related to the fact that, from the $2^{\text {nd }}$ year on, students begin activities of basic supervised training in which the classroom is divided into smaller groups and each group is under the responsibility of one supervisor. Various tasks performed in these training programs require cooperation, in addition to posing conflicts in emerging interpersonal relationships.

No statistically significant differences were found among $3^{\text {rd }}$ year students, therefore the already well adapted to the institution and to people and are more autonomous in the performance of their academic activities. The results, however, show statistically significant differences among $4^{\text {th }}$ year students in regard to the personal and interpersonal items. Concerning the personal item, the $4^{\text {th }}$ year may represent a critical time in the lives of Psychology students in the institution under study, because at this point, supervised training activities are initiated. Of particular interest is clinical training, a time when students have their first contact with individuals from the community who are interested in the psychotherapy service provided by the school clinic at the university. Because these are unusual situations in the lives of psychology students, it is only natural that they experience significant emotional responses, such as anxiety. In regard to difficulties faced in interpersonal relationships, these difficulties may be related not only to the school clinic but also to other supervised training programs developed outside the university, which are also initiated in the $4^{\text {th }}$ year. Finally, significant differences were not found among $5^{\text {th }}$ year students, which may be related to the fact that these students are better adapted to the university. Even though students still attend supervised training programs in the $5^{\text {th }}$ year, apparently these do not pose many difficulties for students, possibly due to the fact that the programs are no longer a novelty by the $5^{\text {th }}$ year.

The study's second analysis involved comparing the $5^{\text {th }}$ year students to those from all the remaining years. Differences were found 
between $1^{\text {st }}$ and $5^{\text {th }}$ year students in regard to the studying, personal and institutional items. This result is understandable because $1^{\text {st }}$ year students are less mature than those in the more advanced years. The difficulties $1^{\text {st }}$ year students experience with studying are possibly due to the fact that enrolling in a undergraduate program represents a big change in their lives, while $5^{\text {th }}$ year students are better adapted. In regard to the personal item, $1^{\text {st }}$ year students are also expected to experience more anxiety because the university represents new experiences, while $5^{\text {th }}$ year students had already been exposed to stressful events. Additionally, $5^{\text {th }}$ year students rarely doubt their choice regarding the program, while $1^{\text {st }}$ year students may still be unsure.

Second year and $5^{\text {th }}$ year students showed significant differences in the interpersonal and institutional items. We have already mentioned that the $2^{\text {nd }}$ year students begin basic supervised training programs in which small groups are formed and each is under the responsibility of one supervisor. In this situation, many of the tasks require cooperation, a context in which interpersonal problems may emerge. This should no longer be a problem for $5^{\text {th }}$ year students since, at this point, they have already been exposed to situations of supervised training involving tasks that require greater cooperation. The $2^{\text {nd }}$ year represents a critical time for the students in the institutional item because the assessments are no longer performed in groups (as is the case in the $1^{\text {st }}$ year). Individual assessments may pose more stress and difficulties for students, who may doubt their choice of program or school, as a result.

The comparison between the $3^{\text {rd }}$ year and $5^{\text {th }}$ year students shows significant differences in the personal item. One variable that would explain this result is integrated assessment, which all $3^{\text {rd }}$ year students in all the programs at the university must take part in. The integrated assessment refers to a test containing a considerable number of multiple-choice and discursive questions addressing content from all the program's courses for a semester, in addition to general knowledge. This special assessment was once applied for $5^{\text {th }}$ year students only, but it was being introduced to the $4^{\text {th }}$ year ( $5^{\text {th }}$ and $6^{\text {th }}$ semesters) students at the time of this study's data collection. Because it was a novelty for these students, it may have being a stressful event, leading students to experience anxiety. The $5^{\text {th }}$ year students, in turn, were better adapted to this assessment. Finally, $4^{\text {th }}$ and $5^{\text {th }}$ year students showed no other differences because both had already faced considerable exposure to the teaching institution, its standards, and to the program itself and related situations.

These results show that the lives of students involve various situations with stressful events that may lead to emotional responses such as anxiety and sleep disorders, among other factors, that are extremely distressful during academic life (Charkha, Abarghuei, \& Hayati, 2013; Fogaça et al., 2012; Pagnin et al., 2014; Yussuf, Issa, \& Buhari, 2013). When facing these situations, people have to develop coping strategies that will result or may result in adapting to adversities the environment imposes (these situations or contexts) (Bardagi \& Hutz, 2011). In Psychology, analyses regarding a topic like this draw the attention of different areas or approaches. According to Sidman (2009), for instance, emotional responses such as anxiety may result from the relationships people establish with their physical and social environments. The physical/ natural environment refers to something that is outside of the body: people are often threatened by the cold, heat, rain, or tsunamis, among other manifestations, and people build shelters, dams, store food, etc., in order to adapt to adversities.

The authors contend that environment also refers to people's bodies (internal environment). In this sense, people perceive that, as they get older, threats that come from their own body's interior intensify. People seek defenses against the constraints of their own bodies by performing routine exams and acquiring health plans, among other measures to ensure their wellbeing.

Sidman (2009) also notes one type of environment with which we establish relationships, while many of these relationships are woefully coercive: the social environment. This type of 
environment refers to other people. In social relationships, people represent environments to each other. People establish relationships and many of these are considered coercive based on the interactions people establish, i.e., children and criminals are punished in order to avoid the repetition of socially unacceptable behavior. In the context of education (primary or higher education), coercion is also present. Many students consider low grades to be a punishment and many study as a means to avoid aversive/stressful events.

Skinner (1972) was an important behavioral analyst and contributed to the topic of education. According to him, experiences at school are loaded with adversities for many years. These experiences are openly aversive. There were times when children in elementary school for instance, performed their tasks to avoid the wooden paddle or rattan cane. Children basically acted to avoid or escape punishment. It occurred in the past and still occurs, based on the numerous aversive events such as teachers' anger, jokes or teasing from peers, competitions and comparisons, low grades, and failure, among others. Therefore, school environments (and university environments, as well) are full of stressors that are always challenging and coercing people and the result is usually harmful side effects, many of which are emotional side effects, such as anxiety.

Skinner (2003) notes that many of the relationships within school (as in many situations of life) are extremely aversive. Many students do not learn or simply give up education possibly because they feel constrained. Studying is, in many cases, maintained in order to avoid aversive events, such as low grades and failure. Studying is seldom maintained under the control of the more natural consequences of learning. Much of what is done at schools is, therefore, correlated with punishment. Skinner is against the use of punishment to exert control; instead he reflects upon the ideal model of school, the school of the future. He considers that instead of schools being undesirable places, schools should be pleasant places free of punishment.

522 Schools should be well-planned facilities with a good appearance. Students should go to school not because they would be punished otherwise, but because they would feel attracted to it.

Based on the previous analysis, we recommend that pedagogical processes integrate and encourage the adoption of healthy lifestyles, leading students to see stimuli received both from the internal and external environment as ordered, structured and clear information, i.e., promoting the resilience to respond to the requirements of a stressful situation.

This study's objective was accomplished based on the assumption that students in higher education present different behavior during their academic trajectory in order to adapt to the college environment. Changes in the personal, family and social contexts may interfere in academic performance when not well administered by the student him/ herself or by the institution. A successful adaptation depends not only on the student, but also on the institution, which has to meet the needs of its students in regard to adapting to institutional standards and assessments. This study sought to describe the academic experiences of a group of psychology students (from the $1^{\text {st }}$ to the $5^{\text {th }}$ years) using a convenience, but limited, sample, which hinders generalization of data.

There is a need to deepen the study of the phenomenon of the "academic experience of Psychology students" in order to expand it to other educational contexts: both public and private schools, taking into account different strategies of evaluation, supervised training and clinical programs to complete the profile of Psychology students.

\section{Contributors}

M. C. FOGAÇA idealizing the research participate in the elaboration of experimental strategy, data collection, tabulation and discussion of the results and preparation of the article. D. C. MATOS and V. D. DI RIENZO participated in the discussion of the results and preparation of the article. J. BORSETTI performed the statistical analysis of the study and discussion of results. L. P. RIBEIRO, R. Z. MARTINS and I. G. SILVA (Psychology students) participated in data collection and tabulation. 


\section{References}

Almeida, L. S., Soares, A. P. C., \& Ferreira, J. A. (2002). Questionário de Vivências Acadêmicas (QVA-r): avaliação do ajustamento dos estudantes universitários. Avaliação Psicológica, 1(2), 81-93.

Bardagi, M. P., \& Hutz, C. S. (2011). Eventos estressores no contexto acadêmico: uma breve revisão da literatura brasileira. Interação em Psicologia, 15(1), 111-119.

Charkhabi, M., Abarghuei, M. A., \& Hayati, D. (2013). The association of academic burnout with self-efficacy and quality of learning experience among Iranian students. Springerp/us, 18(2), 677. http//:dx.doi.org/ 10.1186/2193-1801-2-677

De Rose, J. C. C. (2005). Análise comportamental da aprendizagem de leitura e escrita. Revista Brasileira de Análise do Comportamento, 1(1), 29-50.

Fogaça, M. C., Hamasaki, E. E. M., Barbieri, C. A. P., Borsetti, J., Martins, R. Z., Silva, I. G., \& Ribeiro, L. P. (2012). Burnout em estudantes de Psicologia: diferenças entre alunos iniciantes e concluintes. Aletheia, 38-39, 124-131.

Lopes, C. V., \& Reinaldo, A. M. S. (2012). Contribuição da vivência acadêmica em um centro de convivência de saúde mental na formação do enfermeiro. Cogitare Enfermagem, 17(4), 775-778.

Mognon, J. F., \& Santos, A. A. A. (2013). Relação entre vivência acadêmica e os indicadores de desenvolvimento de carreira em universitários. Revista Brasileira de Orientação Profissional, 14(2), 227-237.

Monteiro, C. F. S., Freitas, J. F. M., \& Ribeiro, A. A. P. (2007). Estresse no cotidiano acadêmico: o olhar dos alunos de enfermagem da Universidade Federal do Piauí. Escola Anna Nery Revista de Enfermagem, 11(1), 66-72.

Oliveira, K. L., \& Santos, A. A. A. (2005). Compreensão em leitura e avaliação da aprendizagem em universitários. Psicologia: Reflexão e Crítica, 18(1), 118-124.
Pagnin, D., Queiroz, V., Carvalho, Y. T., Dutra, A. S., Amaral, M. B., \& Queiroz, T. T. (2014). The relation between Burnout and sleep disorders in medical students. Academic Psychiatry, 38(4), 438-444. http//: dx.doi.org/10.1007/s40596-014-0093-z

Santos, A. A., Suehiro, A. C. B., \& Oliveira, K. L. (2004). Habilidades em compreensão da leitura: um estudo com alunos de Psicologia. Revista Estudos de Psicologia (Campinas), 21(2), 29-41. http://dx.doi.org/10.1590/50 103-166X2004000200003

Sidman, M. (2009). Coerção e suas implicações. São Paulo: Livro Pleno. (Originalmente publicado em 1989).

Silva, E. M. T., \& Witter, G. P. (2008). Compreensão de texto e desempenho acadêmico em estudantes de Psicologia. Estudos de Psicologia (Campinas), 25(3), 395-403. http://dx.doi.org/10.1590/S0103-166X2008 000300008

Skinner, B. F. (1972). Tecnologia do ensino. São Paulo: E.P.U.

Skinner, B. F. (1978). O comportamento verbal. São Paulo: Cultrix. (Originalmente publicado em 1957).

Skinner, B. F. (2003). Questões recentes na análise comportamental. São Paulo: Papirus.

Sousa, H., Bardagi, M. P., \& Nunes, C. H. S. S. (2013). Autoeficácia na formação superior e vivências de universitários cotistas e não cotistas. Avaliação Psicológica, 12(2), 253-261.

Yussuf, A. D., Issa, B. A., \& Buhari, O. I. N. (2013). The correlates of stress, coping styles and psychiatric morbidity in the first year of medical education at a Nigerian University. African Journal of Psychiatry, 16(3), 206-215.

Received: October 17, 2013

Final version: September 23, 2014

Approved: October 6, 2014 
